\title{
Középiskolai tanulók terhelhetőségének mérése egy röplabda tanítási egység közben
}

\section{Measuring Loadability of Secondary School Students during a Teaching Unit of Volleyball}

\author{
Nagy Zsuzsa', Müller Anetta² \\ 1 Budapesti Múszaki Szakképzési Centrum Újpesti Két Tanítási Nyelvú Múszaki Szakgimnáziuma és \\ Szakiskolája, Budapest \\ 2 Eszterházy Károly Egyetem, Sporttudományi Intézet, Eger
}

\begin{abstract}
Absztrakt: Ahhoz, hogy az iskolai testnevelésben az oktató-neveló munka hatékonyságát növelni tudjuk, érdemes megkeresni azokat a módszertani fejlesztési lehetőségeket, amelyek elósegíthetik jövőbeli eredményességét. A tanulmány - tanulók közötti különbségek figyelembevételével - a differenciálás fontosságára és lehetőségére hívja fel a figyelmet az individualizált oktatásban és értékelésben. Az általunk kidolgozott pulzusmérésen alapuló módszer, a különböző képességek, fizikai állapotok figyelembevételével, objektíven támasztja alá a csoportbontást, ezzel együtt a differenciálást a testnevelés órán. A mérés közvetlen célja, hogy a jövőben bizonyíthatóvá váljon a testnevelés még objektívebb értékelése és tervezhetósége. Az általunk modellált új módszer képet ad az adott tanuló tanórai terhelhetőségéról, állóképességi állapotáról (egyénre szabottan), valamint megkönnyíti a tanulók értékelését is. Ugyanakkor segít igazolni az oktatási módszer hatékonyságát, a tanári munka eredményességét.
\end{abstract}

Kulcsszavak: pulzustartomány, motiváció, testnevelés óra

\begin{abstract}
To be able to improve the efficiency of Physical Education lessons in secondary schools, it is worth looking for such methodological development that can facilitate its future effectiveness. The study draws attention to the importance and possibility of differentiation, taking into account the differences among the students (individualized education and assessment). Our tested method based on pulse measurement objectively supports group working as well as differentiation in the light of various skills and physical conditions. The direct aim of the measurement is to make the evaluation and planning of PE lessons more objective. The method modelled by us gives a detailed picture about the tested student's loadability, endurance and physical condition (in a personalised way) besides making the students' evaluation easier. At the same time, it helps to justify the efficiency of the educational method and the teacher's work.
\end{abstract}

Keywords: Derivation, Measuring of Pulse Rate, Motivation, PE lesson

\section{Bevezetés}

A WHO (2010) naponta minimum 60 perces közepes és nagy intenzitású testmozgást ajánl az 5-17 éves életkorú csoportba tartozóknak. A cél a csont, az ízületi és izomrendszer valamint a kardiorespiratorikus állóképesség fejlesztése aerob gyakorlatokkal. Ehhez a napi mozgásszükséglethez, annak kielégítéséhez a testnevelés óra is szerepet játszhat. A mérőmódszerünk segít azt tesztelni, hogy a WHO által megfogalmazott közepes vagy nagy intenzitású terhelést sikerült-e megvalósítani, a mozgásprogram hatékonyságát mérve.

Olyan új módszertani ötlet kidolgozását szeretnénk kialakítani, amely hozzájárul a differenciálás objektív kivitelezéséhez, ezzel egy időben segíti az egyes osztályok tanmeneteinek összeállítását. A kutatás kezdeti szakaszában minden tanár számára elérhető és végrehajtható ez a módszer. A pulzusmérést ugyanis a tanulók hajtják végre, előzetes 
oktatás után, a nyaki területen. A mért pulzusszám figyelembevételével így megállapítható a tanóra egyes szakaszaiban a tanulók terhelése. Az edzéseken hasonló módszert alkalmaznak a közel azonos képességü tanulók felmérésében.

Az általunk modellált új módszer előnye ( Nagy és Müller, 2016), hogy képet ad a tanórán az adott tanuló terhelhetőségéről, állóképességi állapotáról (egyénre szabottan), valamint megkönnyíti a tanulók értékelését is. Ugyanakkor segít igazolni az oktatási módszer hatékonyságát, a tanári munka eredményességét, illetve motiválhatja a tanulókat a rendszeres testmozgásra. Hazai és nemzetközi kutatások tanúságai szerint a mozgásos aktivitás, a sportolási hajlandóság a fiatalok körében fokozatosan csökkenő tendenciát mutat; az életkor elöre haladtával nő az inaktivitás (Hamar, 2005, Bendiková, 2014, Dobay, 2014, Bíró, 2015, Nemzeti Sportstratégia, 2007-2020). Így minden olyan eszköz és módszer kidolgozása fontos lehet, amely motiválja a fiatalokat a testmozgásra.

Vizsgálatunkban kiválasztottunk egy tanítási egységet (röplabda-ősz), ahol a kezdeti szakaszban a csoportbontás kialakítása céljából manuálisan mértük a tanulók intenzitását (pulzusméréssel). A csoportbontásban mért eredményekkel el tudjuk érni, hogy minden tanuló magához mérten közel azonos teljesítményre legyen képes.
Feltételezzük, hogy - minden tanulónak, egyéni méréssel, egy adott időintervallumon belül, azonos tematikus egységben - az új módszerrel lehetővé válik a hiányosságok felmérése és a fejlődés folyamatos mérése. A tematikus egységek hatékonyságának pontos feltérképezése megkönnyítheti az ezen egységekből felépülő tanmenetkészítést, az oktatási módszer kiválasztását, valamint a tanulásszervezés és a tananyag-feldolgozás metodológiai megalapozottságát.

\section{Módszerek}

\section{Minta}

Három csoportra bontottuk a vizsgált osztályt ( $\mathrm{n}=26,15-16$ éves fiúk). Az 1-es csoportba tartoztak azok a tanulók, akik ugyanakkora terhelésre aerob, illetve zsírégető zónába kerültek és a megnyugvási pulzusértékük rossz értéket mutatott.

A 2-es csoportba kerültek azok a tanulók, akik azonos terhelés mellett a zsírégető zónába kerültek, de nem stabilan „jó” a megnyugvási pulzusértékük.

A 3-as csoportban a tanulókat azonos terhelés mellett nem lehetett kimozdítani a komfortzónából, vagy ha a zsírégető zónába kerültek, a megnyugvási pulzusuk ,jō” értéket mutatott.

\section{Mérési eljárás}

POLAR Team 2 System mérőeszközzel mértük fel a tanulókat és manuálisan is folytattunk mérést.

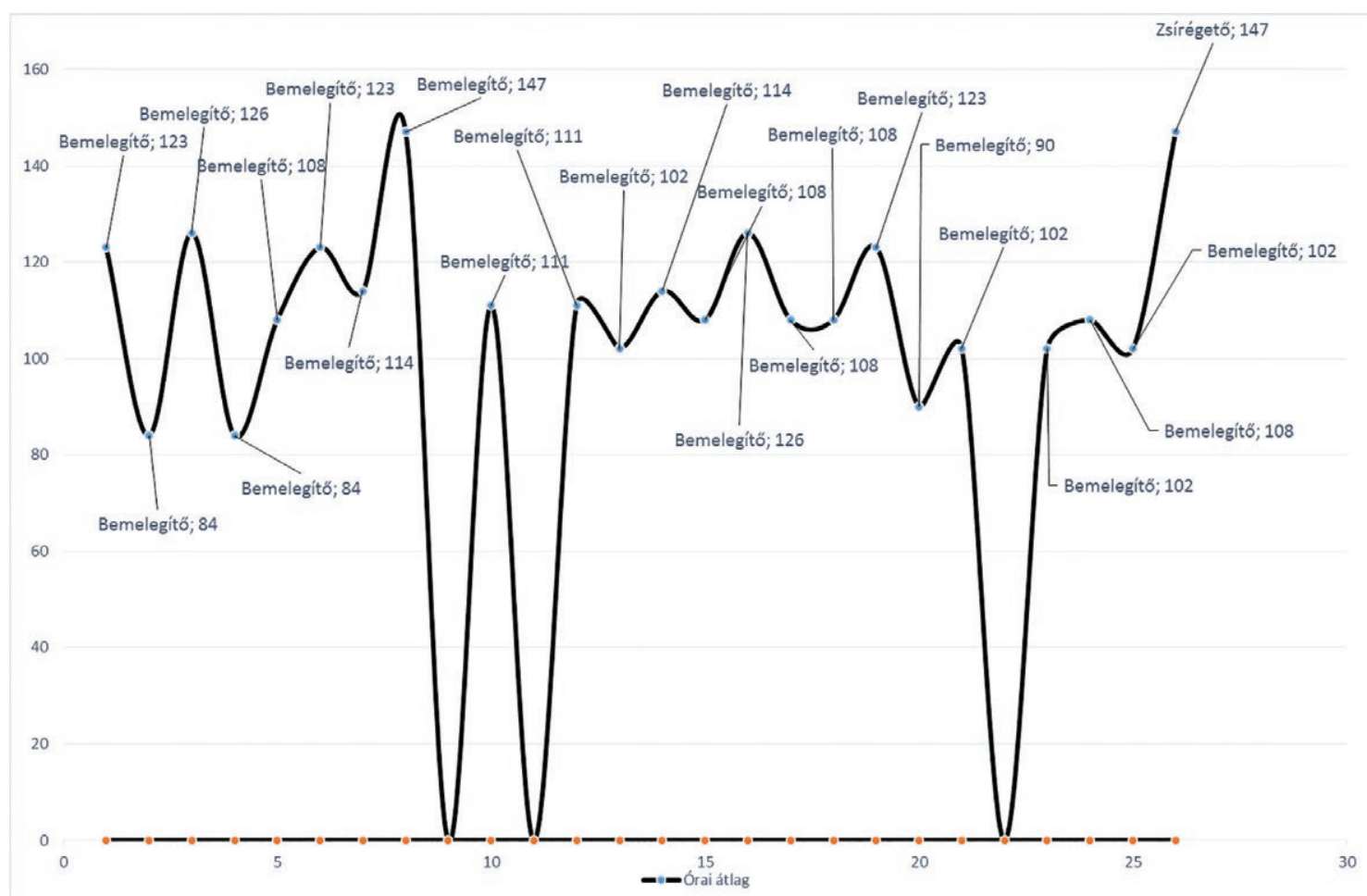

1. ábra. Az első röplabda óra (új ismeretet feldolgozó óra) [forrás: saját szerkesztés] 
A mérés jelentősége abban mutatkozik, hogy az eszköz minden másodpercben méri a vizsgált személy pulzusát és kimutatásokat is végez. $10 \mathrm{db}$ polár öv és jeladó állt a rendelkezésünkre. A három csoportból három tanuló kapta meg ezeket az eszközöket, így őket a polar system segítségével, amíg a csoportok többi tagját manuálisan mértük tovább.

A mérőeszközök száma miatt csoportonként három tanulót választottunk ki. Az azonos tematikus egység második tanítási egységében már csoportbontásban végeztük az oktatást.

\section{Eredmények}

\section{Vizsgálat I.}

A tanulókat nemenkénti bontásban vizsgáltuk, a vizsgált személyek ( $\mathrm{n}=26)$ 15-16 éves fiúk voltak. A tematikus egységek közül a röplabda tanítási egységet választottuk ki. Az első egységben a diagnosztikus értékeléshez azonos terhelés mellett végeztettük a feladatokat. Ennek eredménye adta a csoportbontás szükségességének létjogosultságát.
Az első mért órán kapott eredményekből megállapítható, hogy a tanulók 99\%-a nem lépett ki a komfortzónájából, jelen esetben a bemelegítő zónából (1. ábra). Itt azonban meg kell vizsgálni a megnyugvási pulzust is. Az óra időtartamához viszonyítottuk a pulzusszámot, amit a HRarrive +20 képlettel kaptunk meg. Ez alapján összevethettük az órai munka és a megnyugvási pulzus értékét, amiből megkaptuk a vizsgált órán az aktuális fizikai állapotot.

A tanítási egység első óráján megállapíthattuk, hogy a résztvevő tanulók közül hat regenerálódási ideje nem megfelelö, a hat tanulóból - azonos terhelés mellett - egy tanuló sem lépett ki a bemelegítő zónájából.

A következő órán az ismeretek rögzítése (finom koordinációs szakasz) történt. A mérésekből az derült ki, hogy a tanulók 78\%-a mozdult ki az előző órán tapasztalt komfortzónából. A tanulók 22\%-a saját aerob zónában mozgott az óra fó részében, $26 \%$-a a bemelegítő, míg 52\%-a a zsírégető

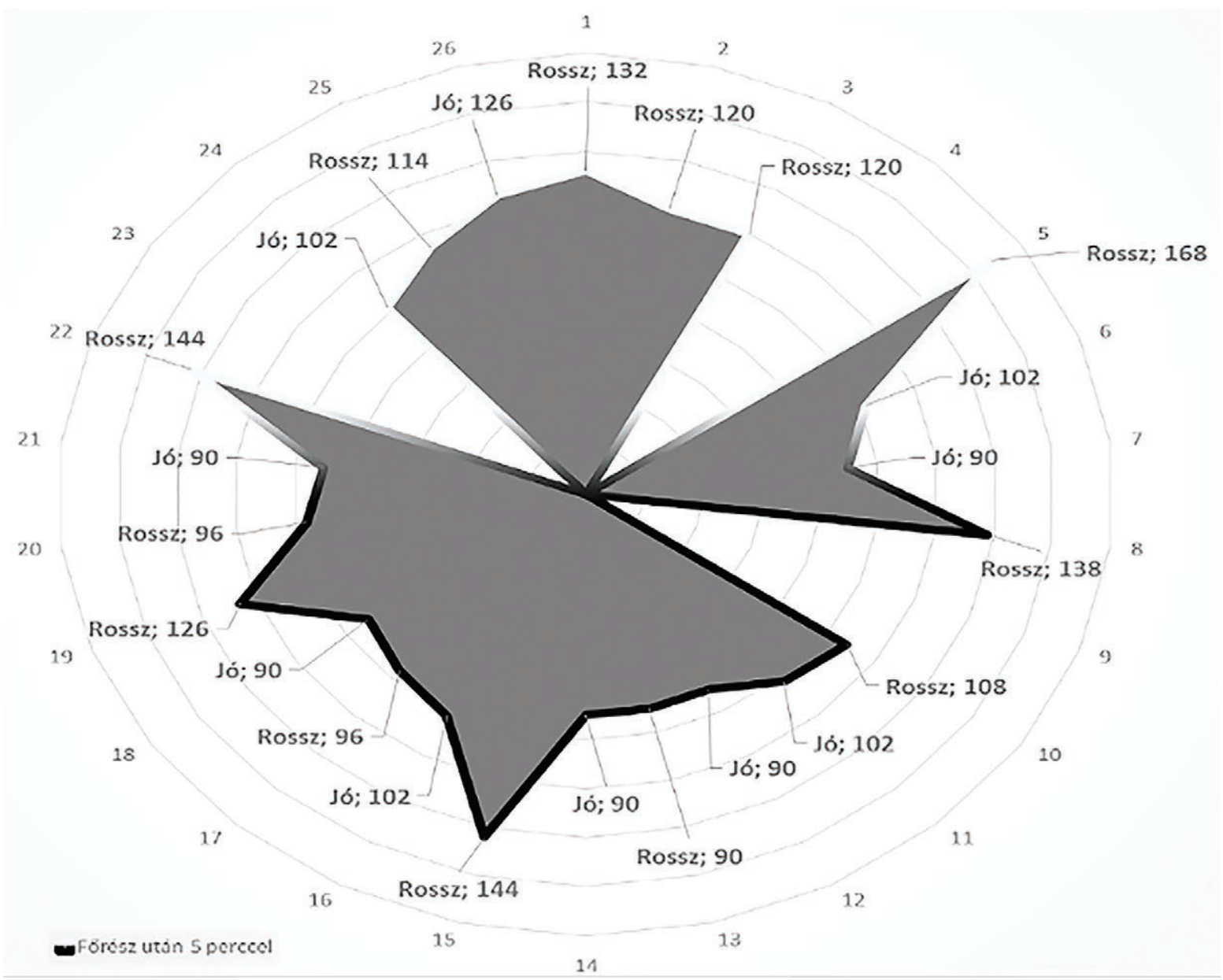

2. ábra. A második órán mért megnyugvási pulzusértékek [forrás: saját szerkesztés] 


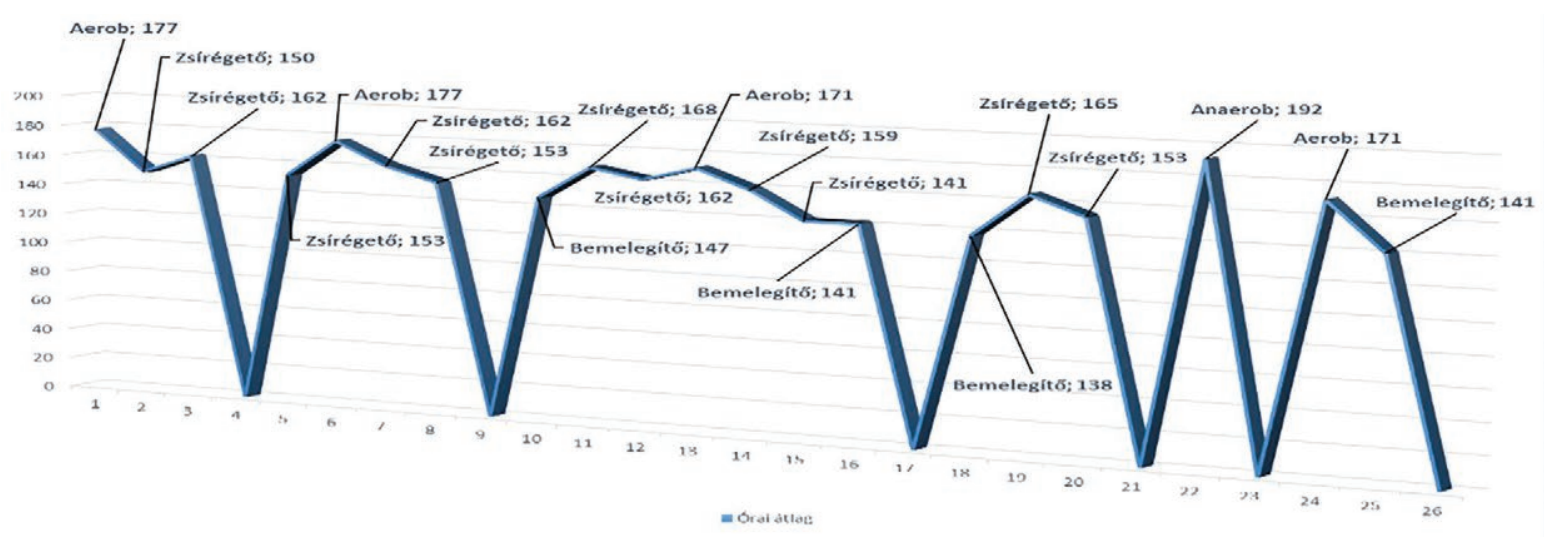

3. ábra. Az utolsó órán mért aktivitás zónákba csoportosítva [forrás: saját szerkesztés]

zónában dolgozott.

Megállapítottuk, hogy aki az aerob zónában mozgott, a megnyugvási pulzusértéke a „rossz” kategóriában volt, tehát a kimenő pulzusa $=$ HRarrive +20. A zsírégető pulzustartományban dolgozó tanulók 41\%-nak volt a megnyugvási pulzusértéke „nem megfelelo"” és a maradék 59\%-nak „megfelelo””. Ezt a későbbi csoportkialakításhoz fontos szempontként kell kezelni. A bemelegítő zónában tartózkodó tanulók 50\%-nak megfelelő a megnyugvási pulzusa (2. ábra).

A szummatív értékelés előtti órán végzett, egyben utolsó mérés ebben a tanítási egységben, együttesen adja a csoport kialakításhoz szükséges információk összességét.
A vizsgált tanulók 50\%-a a zsírégető, $25 \%$-a az aerob zónában, míg 20\%-a a bemelegítési tartományban dolgozott az órán. Egy tanuló az aerob zónában tartózkodott (3. ábra).

Az aerob zónában dolgozó tanulók 40\%-nak volt kevés a megnyugvási pulzusméréshez biztosított idő. A zsírégető pulzustartományban, megnyugvási pulzusértékként, a tanulók felének (50\%) mértünk „rossz” eredményt, míg a bemelegítő tartományban a tanulók 20\%-nak eredménye nem volt megfelelő (4. ábra).

\section{Vizsgálat II.}

A következőkben egy kiválasztott tanuló mérési adatai alapján bemutatjuk a módszer eredményességét.

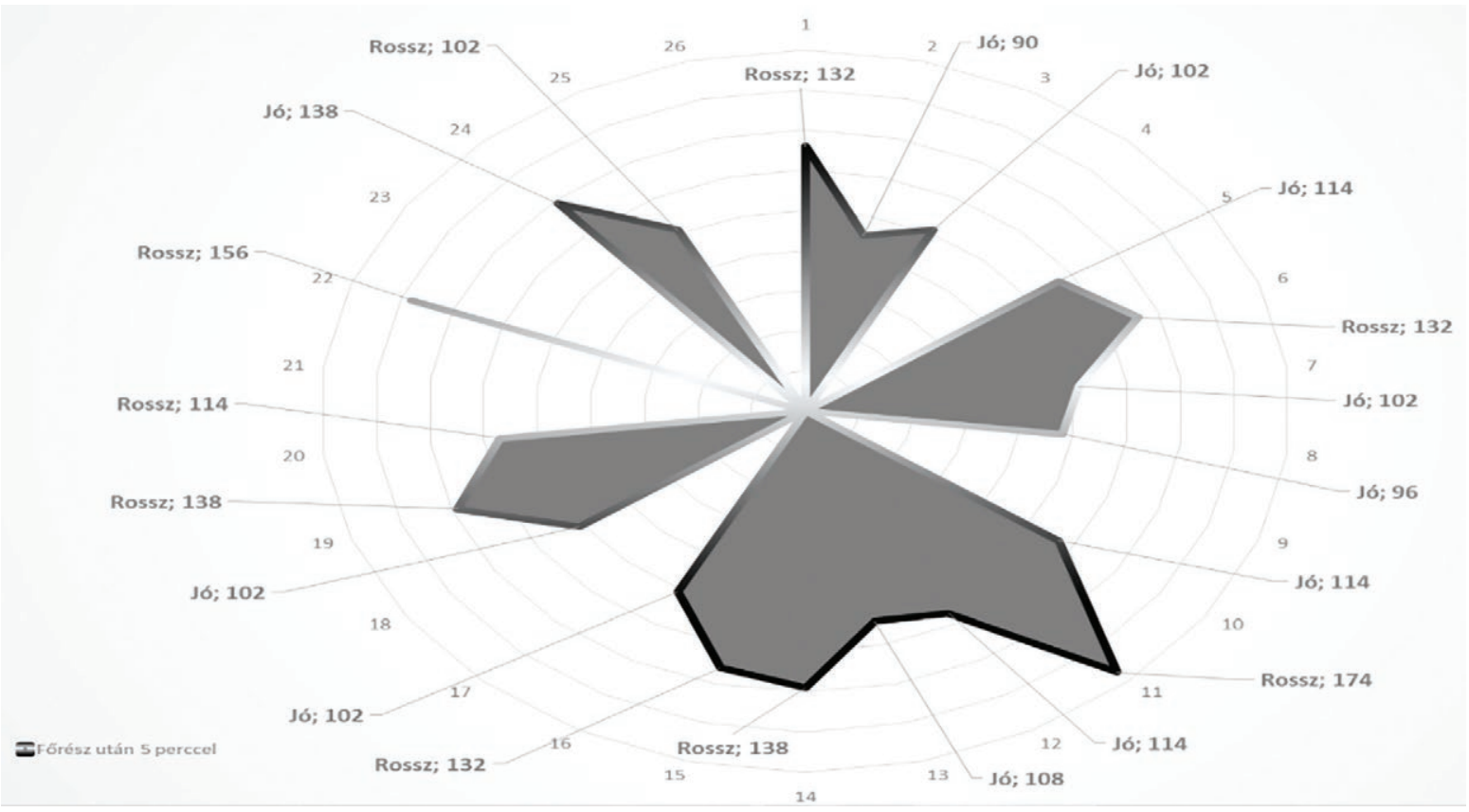

4. ábra. Az utolsó mért óra megnyugvási pulzusa [forrás: saját szerkesztés] 
A 3-as mérőhöz (a 3-as mérő a polár jeladó számára utal) tartozó tanulót az 1-es csoportba soroltuk be. A Netfit adatok közül importáltuk a testmagasságát, a testsúlyát és az életkorát. Az eszközön beállítottuk, hogy a mérés a pulzus megjelenési módjának mindhárom formáját rögzítse ezek: a bpm (ütés/perc), a HRmax\% (max pulzus \%-a) és a HRR\% (terhelés-tartalék \%-a).

Ha a HRmax\% (max pulzus \%-a) számítási módot választjuk a sportzónák számítási alapjaként, akkor az egyes zónák a tanulók maximális pulzusszámának százalékában adhatók meg. Így a zónák - mivel a vizsgált személy egyéni maximális terhelhetőségén alapulnak - személyre szabottak lesznek. Ugyanakkor minden tanulóra ugyanazok az intenzitási százalékok vonatkoznak majd. Amennyiben a
HRR\% (terhelés-tartalék \%-a) számítási módnál a zónák kiszámításának alapja az egyes csapattagoknál/tanulóknál (az osztályt csoportokra osztjuk) megadott határértékek lesznek, akkor minden tanulónál lesz egy felső határérték (anaerob küszöb) és egy alsó határérték (aerob). A határértékeken alapuló számítási mód teszi lehetővé az egyéni terhelés kiszámítását. A terhelés-tartalék a tanulók nyugalmi és maximális pulzusa közötti különbség.

A 3-as mérőhöz tartozó tanuló 17 percet töltött a 70-84\%-os, 8 percet az 55\%-69\%-os és közel 5 percet a $85 \%$ fölötti zónában. Megállapítható, hogy az óra 30 percében 78\%-os intenzitással teljesített. Maximum pulzusához képest elért legmagasabb pulzusa 196 volt, azaz 95\% (5. ábra).

\begin{tabular}{|c|c|c|c|c|c|c|c|c|c|c|c|c|c|c|}
\hline & \multirow{2}{*}{\multicolumn{2}{|c|}{0}} & \multicolumn{3}{|c|}{ HR } & \multicolumn{6}{|c|}{ Time in sport zones } & \multirow{2}{*}{$\begin{array}{c}\text { Above } \\
\text { threshold }\end{array}$} & \multirow{2}{*}{$\begin{array}{c}\text { Training } \\
\text { load }\end{array}$} & \multirow[b]{2}{*}{ Kcal } \\
\hline & & & Minimum & Average & Maximum & $5-24$ & $25-39$ & $40-54$ & $55-69$ & $70-84$ & $85-100$ & & & \\
\hline 3-as mérô & a & $00: 35: 57$ & 0 & 161 & 196 & $00: 00: 53$ & $00: 03: 28$ & 00:01:15 & 00:08:17 & $00: 17: 12$ & 00:04:50 & 00:06:01 & 89 & 516 \\
\hline Max HR: 205 & & & $0,0 \%$ & $78,0 \%$ & $95,0 \%$ & $2,5 \%$ & $9,6 \%$ & $3,5 \%$ & $23,1 \%$ & $47,9 \%$ & $13,4 \%$ & $16,7 \%$ & $95,7 \%$ & $92,8 \%$ \\
\hline
\end{tabular}

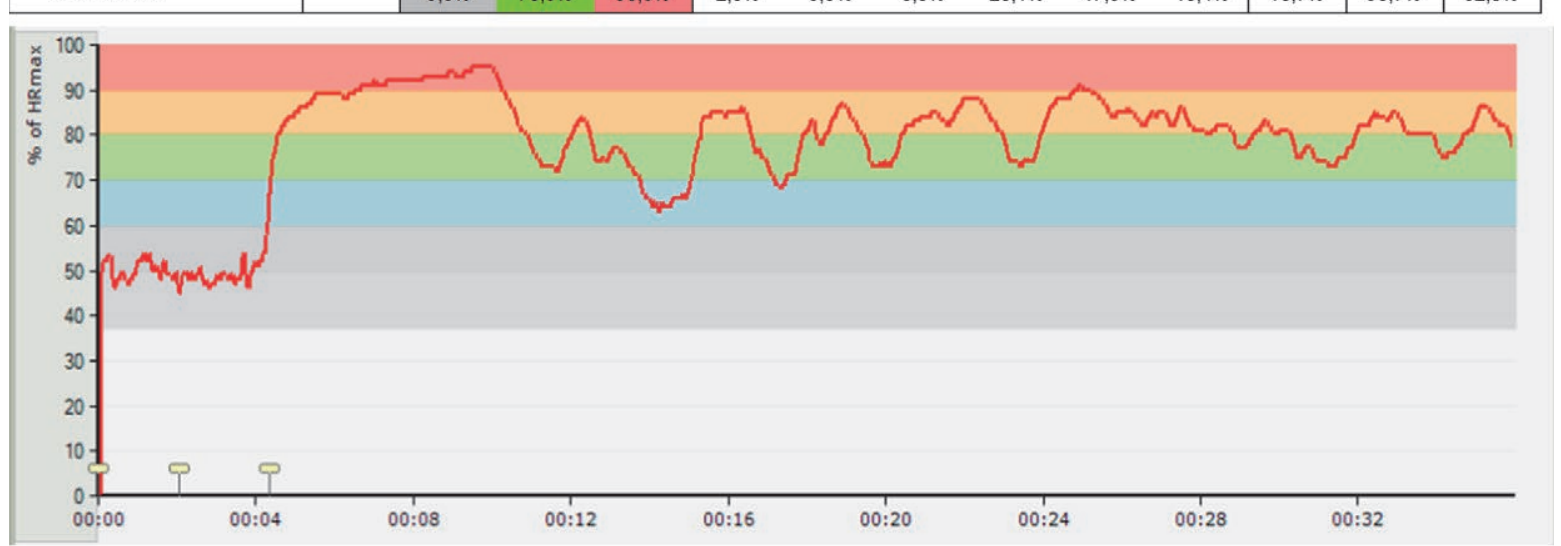

POEAR.

5. ábra. A 3-as számú mérőhöz tartozó tanuló első mért órai HRmax \%-os teljesítménye [forrás: Polar System mérése alapján saját szerkesztés]

A második mért tanóra során több időt töltött a tanuló a 70-84\%-os intenzitású (16’) és kevesebb időt a 40-54\%-os zónában. Ennek jelentősége, hogy a tanuló az előre meghatározott intenzitással, az óra jellegétől függően, a szervezet számára optimális zónában töltsön több időt. Az órán 78\%-os intenzitással vett részt a tanuló, a legmagasabb pulzusérték a max pulzusához képes 94\%.

A két óra összehasonlításában közel azonos eredményt kaptunk. A célkitűzésünket elértük, azaz a tanuló az óra nagyobb részében, a feladat végrehajtása közben legalább 70\%-os intenzitással végezze a feladatot (6. ábra).

A 2-es csoportba tartozó 5-ös méröjü (az 5-ös mérő a polár jeladó számára utal) tanuló első órán mért eredménye: a tanuló az órán 77\%-os intenzitással végezte a feladatokat. Értékelhető intenzitást több mint 28 percben teljesített. A legmagasabb pulzusa 188 volt, azaz a maximális pulzusához képest $91 \%$.

A következő röplabda órán 31 percet töltött 72\%-os intenzitással, vagyis az 55\%-84\%-os zónán belül 29 percet, míg $85 \%$ felett 2 percet (7. ábra).

$\mathrm{Az}$ utolsó csoport 10-es mérőjü tanulójának (a 10-es mérő a polár jeladó számára utal) a két mért óra együttes diagramjából leolvasható, hogy a tanuló az első mért órán a 3-as csoport tagjakén (a hármas csoport a leginkább terhelhető tanulók 
csoportja) 13 percet töltött az 55\%-69\%-os zónában, míg 12 percet a 70-84\%-os zónában. Az első mért órán átlagosan $76 \%$-os volt az intenzitása, a max pulzusához képest $89 \%$ volt a legmagasabb pulzusszáma (azaz 184). A következő mért órán közel 30 percet dolgozott értékelhető intenzitással. 74\%-os volt a teljesítménye a max pulzusához viszonyítva. Az elért legmagasabb pulzusszáma ezen az órán sem közelítette meg a maximális pulzusszámát (8. ábra).

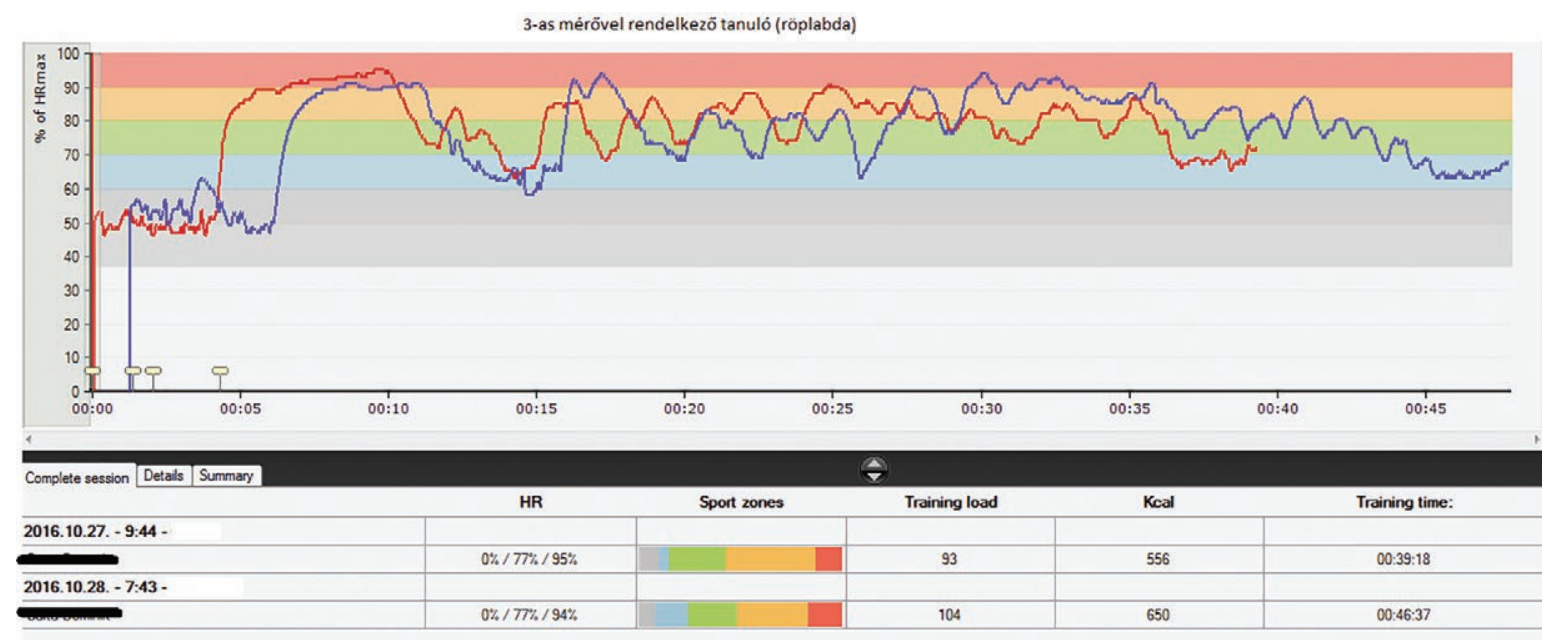

6. ábra. A 3-as számú mérőhöz tartozó tanuló két mért órai teljesítményének összehasonlítása [forrás: Polar System mérése alapján saját szerkesztés]

Training Session Report

\begin{tabular}{|c|c|c|c|c|c|c|c|c|c|c|c|c|c|c|}
\hline & & \multirow{2}{*}{3} & \multicolumn{3}{|c|}{ HR } & \multicolumn{6}{|c|}{ Time in sport zones } & \multirow{2}{*}{$\begin{array}{c}\text { Above } \\
\text { threshold }\end{array}$} & \multirow{2}{*}{$\begin{array}{c}\text { Training } \\
\text { load }\end{array}$} & \multirow[b]{2}{*}{ Kcal } \\
\hline & & & Minimum & Average & Maximum & $5-24$ & $25-39$ & $40-54$ & $55-69$ & $70-84$ & $85-100$ & & & \\
\hline 5-ös mérö & in & $00: 47: 19$ & 0 & 149 & 193 & 00:00:09 & $00: 04: 40$ & $00: 11: 08$ & $00: 15: 59$ & $00: 13: 08$ & $00: 02: 13$ & \begin{tabular}{|l|}
$00: 03: 16$ \\
\end{tabular} & 86 & 533 \\
\hline Max HR: 205 & & & $0,0 \%$ & $72,0 \%$ & $94,0 \%$ & $0,3 \%$ & $9,9 \%$ & $23,5 \%$ & $33,8 \%$ & $27,8 \%$ & $4,7 \%$ & $6,9 \%$ & $100,0 \%$ & $100,0 \%$ \\
\hline
\end{tabular}

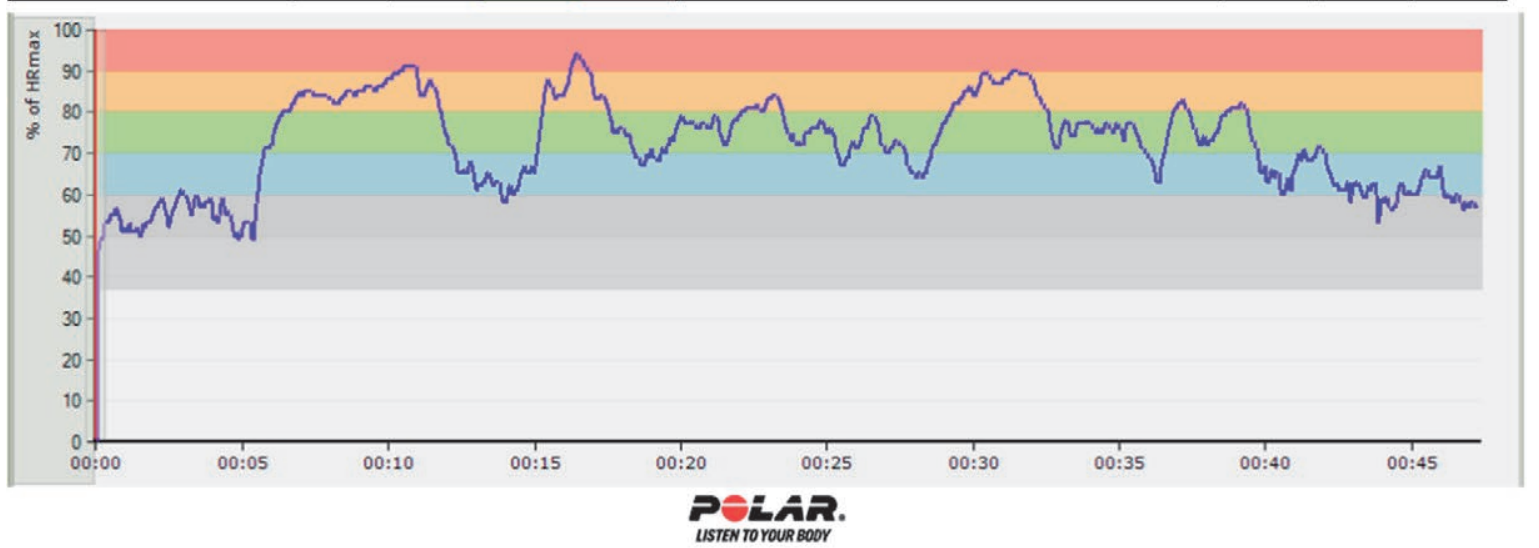

7. ábra. A 2-es csoportba tartozó 5-ös mérőjủ tanuló második órán mért eredménye [forrás: Polar System mérése alapján saját szerkesztés]

A csoportbontás és a megválasztott feladatok ebben a csoportban is eredményesek voltak.

A három csoportból egy tanuló nem teljesítette az előre meghatározott intenzitást, aminek megvizsgáltuk az okát. Ellenőrizve a másodpercenkénti pulzusát és összevetve a többi tanuló azonos időben mért pulzusával, arra lehet következtetni, hogy a feladatok az állapotához képest nem megfelelő szintűek voltak, mivel nem emelkedett relevánsan a pulzusa. Azoknál a feladatoknál azonban, ahol a hármas számú csoport a kizárólagos figyelmemet élvezhette, a pulzusa kimozdult és elérte a feladat 
közben a 75\%-os intenzitást. Ebből arra lehet következtetni, hogy a tanuló akkor végzi megfelelő intenzitással a feladatot, amikor folyamatos ellenőrzés alatt áll. Ez igazolja a tanári módszerek közül az interakció, a folyamatos megfigyelés és ellenőrzés nélkülözhetetlen szerepét. A módszer eredményessége a testnevelö tanárok kezében eszköz lehet ahhoz, hogy a pulzusszám változás alapján megállapíthassák a különböző terhelhetőségü tanulók teljesítményét. A testnevelésórán is bizonyítható - objektív adatokkal alátámasztott - legyen az értékelés.

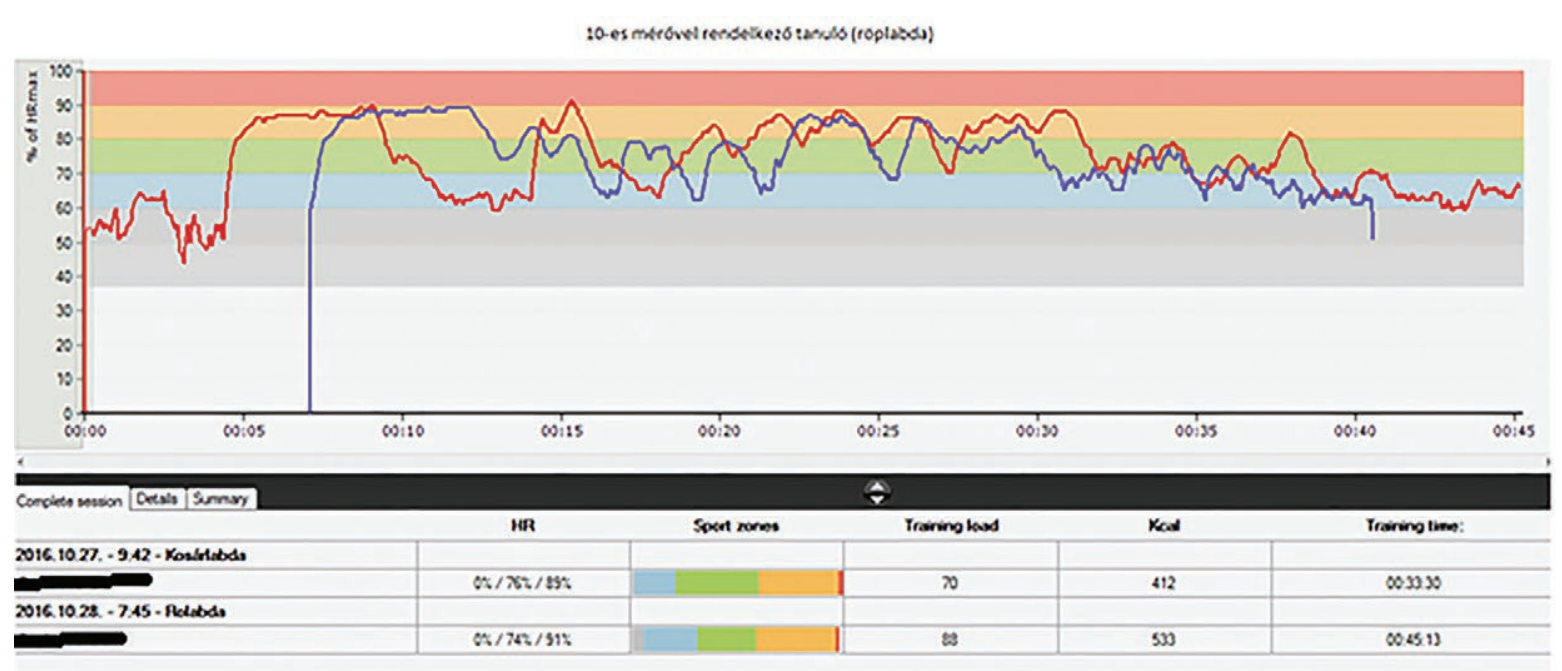

8. ábra. A 10-es mérőjű tanuló két mért órai teljesítménye [forrás: Polar System mérése alapján saját szerkesztés]

\section{Megbeszélés}

A pontosabb mérések eléréséhez, a folyamatos ellenőrzés biztosításához a pulzusmérő pántok számának növelése javasolt, ezzel könnyítve meg az adatkezelést. A módszer, Netfit adatokkal egyetemben, hozzájárulhat a még több következtetés levonásához. (Amíg a Netfitben az aerob fittségi (állóképességi) profil egy tesztet tartalmaz, addig ezzel a módszerrel, egy folyamatos ellenőrzési rendszerrel alátámaszthatjuk a diagnosztikus értékelést.)

Ennek a rendszernek a használata lehetővé teheti, hogy a pedagógus szakma e területén is bekövetkezzen a nélkülözhetetlen szemléletváltás, ahol a megítélés alapja nem a rövidtávú jóérzéstől függ, hanem a hosszú távon, kemény munkával elért fejlődésről szól.

A pulzusmérés szerepével, lehetőségeivel a tanulókat is meg kell ismertetni, hiszen a NAT célként fogalmazza meg az életvezetési kompetenciák fejlesztését, az egészségtudatos-szemléletmód kialakítását és azt, hogy a tanulók legyenek tisztában a fittség megőrzésében, megtartásában szerepet játszó mozgásos tevékenységekkel, azok mérésével. Amennyiben a tanuló ebben az életkorban megtanulja használni és értelmezni a pulzustartományok terhelés-módszertani aspektusait, talán felnőtt korban is fogékonyabb lesz az egészségtudatos szemlélet érvényesítésére. A pulzusmérés szerepe egyaránt nélkülözhetetlen a rekreációs edzés területén és az egészségtudatosság megvalósításában (Müller és Rácz, 2011).

\section{Irodalom}

1. Bendíková, E. (2014): Lifestyle, physical and sports education and health benefits of physical activity. European Researcher: International Multidisciplinary Journal, 69(2-2): 343-348.

2. Bíró Melinda (2015): A testnevelés aktuális kérdései. In: Révész László és Csányi Tamás (szerk.). Tudományos alapok a testnevelés tanitásához. I. kötet: Szemelvények a testnevelés, a testmozgás és az iskolai sport tárgyköréböl. Társdalom-természet-és orvostudományi nézöpontok. MDSZ, Budapest. 105-136.

3. Dobay Beáta (2014): A Selye János Egyetem óvópedagógus hallgatói körében végzett felmérés a testmozgás tükrében. „Oktatás és tudomány a 
XXI. század elején”. Nemzetközi Tudományos Konferencia tanulmánykötete. 69-71.

4. Hamar Pál (2005): A rendszeres testedzés helye és szerepe a serdülőkorú lányok életvitelében. Ujj Pedagógiai Szemle, 55(10): 68-75.

5. Müller Anetta és Rácz Ildikó (2011): Aerobic és Fitness irányzatok. Dialóg Campus Kiadó, Budapest-Pécs.

6. Nagy Zsuzsa és Müller Anetta (2016): The Role of the Pulse Measurement in the Students' Differentiated Education Applied in PE. (515). Physical Activity, Health and Prevention, Banská Bystrica.
7. Nemzeti Sportstratégia (2007-2020): Sport XXI. Nemzeti Sportstratégiáról. htp://www. kobanyasc.hu/docs/ 07sportstrategia.pdf (Letöltés: 2017.01.22.)

8. World Health Organization (2010): Global recommendations on physical activity for health. 7. http://apps.who.int/iris/bitstre am/10665/44399/1/9789241599979_eng. pdf (Letöltés: 2017.01.22.) 